\title{
KEWENANGAN PENGADILAN NEGERI DALAM MEMUTUS SENGKETA LELANG PERBANKAN SYARIAH
}

\author{
Grace Immanuel Limongan \\ graceimanuel11@gmail.com \\ Universitas Airlangga
}

\begin{abstract}
One of the important solutions that must be considered by the government in recovering Indonesian economy is implementing sharia economy. Sharia economy has a strong commitment on poverty alleviation, enforcement of justice, economical growth, elimination of usury and prohibition of currency speculation, thus creating economic stability. Sharia economy which emphasizes justice, teaches concepts that excel in dealing with monetary turmoil compared to conventional systems. This fact has been widely acknowledged by many global economic experts, such as Rodney Shakespeare (United Kingdom), Volker Nienhaus (Germany), etc. Going forward, government must pay more attention to the sharia economy system that has been proven to be effective and more resistant in crisis.

Sharia economy system represented by sharia banking institutions have shown to be resilience since it uses a profit sharing system, so that it does not experience negative spread as other conventional banks are. In fact, sharia banking grows in difficult times.Meanwhile, large banks experienced severe downturn which ended in liquidation, some other conventional banks were forced to be recapitulated by the government in a large amount. The budget funds that should be prioritized alleviate people's poverty, was used to help conventional banks. This is the fact that happens when still using and hold ribawi sharia economics. Therefore, the government is now more concerned with the development of sharia economics in Indonesia, both through ratification of laws and by establishing sharia financial institutions.
\end{abstract}

Keyword : Sharia Economy, Sharia Banking, Financial Institutions

\begin{abstract}
Abstrak
Salah satu solusi penting yang harus diperhatikan pemerintah dalam me-recovery ekonomi Indonesia adalah menerapkan ekonomi syariah. Ekonomi syariah memiliki komitmen yang kuat pada pengentasan kemiskinan, penegakkan keadilan, pertumbuhan ekonomi, penghapusan riba, dan pelarangan spekulasi mata uang sehingga menciptakan stabilitas perekonomian. Ekonomi syariah yang menekankan keadilan, mengajarkan konsep yang unggul dalam menghadapi gejolak moneter dibanding sistem konvensional. Fakta ini telah diakui oleh banyak pakar ekonomi global seperti Rodney Shakespeare (United Kingdom), Volker Nienhaus (Jerman), dan sebagainya. Kedepannya, pemerintah harus lebih memperhatikan sistem ekonomi syariah yang telah terbukti ampuh dan lebih resisten di masa krisis.

Sistem ekonomi syariah yang diwakili lembaga perbankan syariah telah menunjukkan ketangguhan bisa bertahan karena ia menggunakan sistem bagi hasil sehingga tidak mengalami negative spread sebagaimana bank-bank konvensional. Bahkan, perbankan syariah semakin berkembang dimasa-masa sulit tersebut. Sementara bank-bank raksasa mengalami keterpurukan hebat yang berakhir pada likuidasi, sebagian bank konvensional lainnya terpaksa direkap oleh pemerintah dalam jumlah besar. Dana APBN yang seharusnya diutamakan untuk mengentaskan kemiskinan rakyat, tetapi digunakan untuk membantu bank-bank konvensional. Inilah faktanya kalau masih mempertahankan ekonomi kapitalis yang ribawi. Karena itu pemerintah sekarang lebih konsen terhadap perkembangan ekonomi syariah di Indonesia, baik melalui pengesahan undang-undang maupun dengan mendirikan lembaga keuangan syariah.
\end{abstract}

Kata Kunci : Ekonomi Syariah, Perbankan Syariah, Lembaga Keuangan 


\section{A. PENDAHULUAN}

\section{Latar Belakang}

Salah satu solusi solusi penting yang harus diperhatikan pemerintah dalam merecovery ekonomi Indonesia adalah menerapkan ekonomi syariah. Ekonomi syariah memiliki komitmen yang kuat pada pengentasan kemiskinan, penegakkan keadilan, pertumbuhan ekonomi, penghapusan riba, dan pelarangan spekulasi mata uang sehingga menciptakan stabilitas perekonomian. Ekonomi syariah yang menekankan keadilan, mengajarkan konsep yang unggul dalam menghadapi gejolak moneter dibanding sistem konvensional. Fakta ini telah diakui oleh banyak pakar ekonomi global seperti Rodney Shakespeare (United Kingdom), Volker Nienhaus (Jerman), dan sebagainya. Kedepannya, pemerintah harus lebih memperhatikan sistem ekonomi syariah yang telah terbukti ampuh dan lebih resisten di masa krisis. Sistem ekonomi syariah yang diwakili lembaga perbankan syariah telah menunjukkan ketangguhan bisa bertahan karena ia menggunakan sistem bagi hasil sehingga tidak mengalami negative spread sebagaimana bank-bank konvensional. Bahkan, perbankan syariah semakin berkembang dimasa-masa sulit tersebut.

Sementara bank-bank raksasa mengalami keterpurukan hebat yang berakhir pada likuidasi, sebagian bank konvensional lainnya terpaksa direkap oleh pemerintah dalam jumlah besar. Dana APBN yang seharusnya diutamakan untuk mengentaskan kemiskinan rakyat, tetapi digunakan untuk membantu bank-bank konvensional. Inilah faktanya kalau masih mempertahankan ekonomi kapitalis yang ribawi. Karena itu pemerintah sekarang lebih konsen terhadap perkembangan ekonomi syariah di Indonesia, baik melalui pengesahan undang-undang maupun dengan mendirikan lembaga keuangan syariah. Eksistensi Bank dalam memajukan perekonomian negara semakin besar dengan disahkannya Undang-Undang Nomor 21 Tahun 2008 (selanjutnya disebut UU Perbankan Syariah), hal tersebut seakan memberikan angin segar kepada perbankan untuk lebih mengembangkan dan memajukan program yang dilakukan perbankan. Adapun tujuan dikeluarkan serta disahkannya UU Perbankan Syariah adalah untuk menghindari adanya praktek bunga yang terdapat pada perbankan konvensional dan dirubah dengan program investasi serta bagi hasil yang sesuai dengan aturan syariah.

Sebagaimana yang telah dijelaskan dalam UU Perbankan Syariah, syariah adalah segala sesuatu yang menyangkut tentang Bank Syariah dan Unit Usaha Syariah, mencakup kelembagaan, kegiatan usaha, serta cara dan proses dalam melaksanakan kegiatan usahanya, 
sedangkan Bank Syariah menurut Pasal 1 angka 7 UU Perbankan Syariah adalah Bank yang menjalankan kegiatan usahanya berdasarkan Prinsip Syariah dan menurut jenisnya terdiri atas Bank Umum Syariah dan Bank Pembiayaan Rakyat Syariah. Perbankan syariah menjalankan kegiatan usaha berdasarkan prinsip syariah adalah prinsip hukum Islam dalam kegiatan perbankan berdasarkan fatwa yang dikeluarkan oleh lembaga yang memiliki kewenangan dalam penetapan fatwa di bidang syariah, yang berarti bahwa Bank Syariah menjalankan kegiatan usaha berbeda dengan kegiatan usaha bank konvensional. Adapun mengenai prinsip syariah dalam perbankan adalah:

Prinsip syariah adalah aturan akad berdasarkan hukum Islam antara bank dengan pihak lain untuk menyimpan dana dan atau pembiayaan kegiatan usaha, atau kegiatan lainnya yang dinyatakan sesuai dengan syariah, antara lain, berdasarkan prinsip bagi hasil (mudharabah), pembiayaan berdasarkan prinsip penyertaan modal (musharakah), prinsip jual beli barang dengan memperoleh keuntungan (murabahah) atau pembiayaan barang modal berdasarkan prinsip sewa murni tanpa pilihan (ijarah), atau dengan adanya pilihan pemindahan kepemilikan atas barang yang disewa dari pihak bank oleh pihak lain (ijarah wa iqtina). ${ }^{1}$

Seiring dengan perkembangan zaman, minat masyarakat terhadap perbankan syariah semakin meningkat, hal tersebut bisa dilihat dari semakin banyaknya dana yang disalurkan oleh perbankan syariah kepada masyarakat dengan menggunakan beberapa macam skim yang dimiliki oleh perbankan syariah. Bank syariah yang berfungsi sebagai lembaga intermediasi mempunyai beberapa tugas utama yakni sebagai tempat penghimpunan dana dengan bentuk tabungan, giro, dan deposito yang menggunakan skim wadiah dan amanah, dan disalurkan kepada masyarakat dengan beberapa skim yang tentunya berbeda dengan bank konvensional. ${ }^{2}$

Berdasarkan fungsi intermediasi tersebut, maka bank melakukan aktivitas berupa penyaluran dana kepada para pengusaha yang memerlukan campur tangan pihak perbankan dalam hal permodalan, bisa modal sebagian bisa juga modal keseluruhan ditanggung pihak bank yang menjadi mitra usaha. Fungsi penyaluran dana ini selain bisa meningkatkan perekonomian masyarakat karena bisa mengatasi masalah permodalan bagi para pengusaha, juga bisa meningkatkan aktivitas bank yang berpengaruh terhadap meningkatnya pendapatan bank yang pada akhirnya juga meningkatkan dana nasabah penyimpan dana.

\footnotetext{
${ }^{1}$ Rachmadi Usman, Produk dan Akad Perbankan Syariah di Indonesia, Citra Aditya Bakti, Bandung, 2009, hlm. 16.

2 Pius A Partanto, Kamus Ilmiah Populer, Arkola, Surabaya, 2001, hlm. 72.
} 
Pembiayaan yang diberikan bank syariah bertujuan untuk memfasilitasi kebutuhan masyarakat terhadap pembiayaan yang sesuai dengan syariah Islam, memenuhi kebutuhan nasabah yang frekuensi transaksinya banyak dan seringkali memerlukan tambahan dana dalam jangka pendek, membiayai usaha nasabah dan terhadap pembelian barang konsumsi, serta memperoleh keuntungan sebagai perusahaan atau bank.

Dalam pembiayaan yang dilakukan bank syariah, bank syariah mendapatkan keuntungan melalui bagi hasil sesuai nisbah yang telah disepakati antara nasabah dengan pihak bank dalam akad maupun margin atas pembiayaan yang berbasis akad murabahah. Berbeda dengan bank konvensional, hubungan antara bank syariah dengan nasabah pembiayaan bukan hubungan antara kreditur dengan debitur, melainkan hubungan kemitraan antara penyandang dana (shahibul mal) dengan pengelola dana (mudarib), hubungan yang memiliki keterikatan emosional sehingga diharapkan bank syariah dalam menangani pembiayaan yang bermasalah, khususnya untuk proses pelelangan agunan juga harus memperhatikan hak-hak nasabah. Ini dimaksudkan agar proses pelelangan agunan ini bisa menguntungkan kedua belah pihak atau tidak merugikan salah satu pihak. Berdasarkan apa yang diuraikan diatas, Jurnal yang berjudul Kewenangan Pengadilan Negeri Dalam Memutus Sengketa Lelang Perbankan Syariah. Berfokus pada permasalahan hukum mengenai apakah Pengadilan Negeri masih berwenang menangani sengketa lelang agunan perbankan syariah setelah adanya PERMA Nomor 14 Tahun 2006 dan apa saja bentuk perlindungan hukum debitur apabila sengketa lelang perbankan syariah sudah ditetapkan oleh Pengadilan Negeri.

\section{Tujuan Penelitian}

Penelitian ini bertujuan untuk menganalisis tentang Kewenangan Pengadilan Negeri Dalam Memutus Sengketa Lelang Perbankan Syariah. Berfokus pada permasalahan hukum mengenai apakah Pengadilan Negeri masih berwenang menangani sengketa lelang agunan perbankan syariah setelah adanya PERMA Nomor 14 Tahun 2006 dan apa saja bentuk perlindungan hukum debitur apabila sengketa lelang perbankan syariah sudah ditetapkan oleh Pengadilan Negeri.

\section{Manfaat Penelitian}

Dari segi teoritik penelitian ini diharapkan berguna bagi pengembangan hukum Perbankan, khususnya hukum perbankan Syariah. Dari segi praktis penelitian ini diharapkan 
dapat berguna bagi praktik hukum misalnya penegakan hukum mengenai penanganan kasus atau permasalahan-permasalahan hukum yang berkaitan dengan perbankkan syariah.

\section{Metode Penelitian}

Penelitian ini merupakan penelitian hukum normatif, bertujuan mencari pemecahan atas isu hukum yang timbul didalamnya, sehingga hasil yang dicapai adalah memberikan preskripsi mengenai apa yang seyogyanya atas isu hukum yang diajukan. Pendekatan yang digunakan adalah pendekatan perundang-undangan (statute approach), pendekatan konseptual (conceptual approach), dan pendekatan kasus (case approach). ${ }^{3}$ Metode analisis bahan hukum didasarkan pada bahan hukum primer berupa perundanganundangan dikumpulkan dengan metode inventarisasi dan kategorisasi.

\section{B. PEMBAHASAN}

\section{Pengadilan Negeri Masih Berwenang Menangani Sengketa Lelang Agunan Perbankan Syariah Setelah Adanya PERMA Nomor 14 Tahun 2006 a. Kewenangan Pengadilan Negeri Dalam Menangani Lelang Perbankan Syariah}

Seperti diketahui selama ini, jika terjadi sengketa atau perselisihan antara pihak bank syariah dengan nasabahnya, maka alternatif penyelesaian antara pihak bank syariah dengan nasabahnya, maka alternatif penyelesaiannya adalah Badan Arbitrase yang menerapkan hukum materiil Islam, dalam hal ini adalah Badan Arbitrase Syariah Nasional (BASYARNAS) atau Peradilan Umum sesuai dengan Undang-Undang Nomor 2 Tahun 1986. Dalam literatur sejarah hukum Islam, arbitrase lebih identik dengan istilah tahkim atau hakam. Istilah ini secara literal berarti mengangkat sebagai wasit atau juru damai. ${ }^{4}$ Menurut Undang-Undang Nomor 30 Tahun 1999 tentang Arbitrase (selanjutnya disebut UU Arbitrase), yang dimaksud dengan arbitrase adalah cara penyelesaian suatu sengketa perdata diluar peradilan umum, yang didasarkan pada perjanjian arbitrase yang dibuat secara tertulis oleh para pihak yang bersengketa (vide Pasal 1 ayat (1) UU Arbitrase).

Setelah berlakunya Undang-Undang Nomor 3 Tahun 2006 tentang Perubahan Atas Undang-Undang Nomor 7 Tahun 1989 Tentang Peradilan Agama dan UndangUndang Nomor 21 Tahun 2008 Tentang Perbankan Syariah, jika terjadi sengketa

\footnotetext{
${ }^{3}$ Peter Mahmud Marzuki, Penelitian Hukum, Kencana Prenada Media Group, Jakarta, 2005, hlm, 113

4 Mardani, Hukum Acara Perdata Peradilan Agama dan Mahkmah Syariah, Sinar Grafika, Jakarta, 2009, hlm. 69
} 
perbankan syariah, maka alternatif penyelesaiannya disamping BASYARNAS tersebut, juga Peradilan Agama selaku institusi yang berwenang untuk itu. Hal ini sesuai dengan ketentuan Pasal 49 berikut penjelasannya pada huruf (i) Undang-Undang Peradilan Agama dan Pasal 55 ayat (1) Undang-Undang Perbankan Syariah.

Mahkamah Agung Republik Indonesia telah mengeluarkan Peraturan Mahkamah Agung (selanjutnya disebut PERMA) RI Nomor 14 Tahun 2016 tentang Tata Cara Penyelesaian Sengketa Ekonomi Syariah. Sebenarnya PERMA ini sudah ditunggu pembentukannya sejak lama sebagai pelengkap dari berlakunya Peraturan Mahkamah Agung (selanjutnya disebut PERMA Nomor 2 Tahun 2008 tentang Kompilasi Hukum Ekonomi Syariah (selanjutnya disebut KHES). Bila terjadinya kekosongan hukum acara, penyelesaian sengketa ekonomi atau bisnis syariah masih tunduk pada ketentuan hukum acara perdata yang biasa di lingkungan peradilan negeri. Walaupun sengketa ekonomi yang berdasarkan prinsip syariah, namun dalam penggunaannya masih berkiblat pada sistem hukum peninggalan kolonial belanda. Adanya PERMA ini juga berdampak pada implementasi Pasal 49 Undang-Undang Nomor 3 Tahun 2006 tentang Peradilan Agama akibat berkembangnya ekonomi syariah. Seperti, penyelesaian perkara ekonomi syariah dapat dilakukan melalui hukum acara biasa atau dalam bentuk gugatan sederhana (small claim court) baik secara lisan maupun tertulis ke Kepaniteraan Pengadilan Agama yang berwenang. Sebagaimana yang tertuang dalam Pasal 2 PERMA Sengketa Ekonomi Syariah yang menyebutkan bahwa perkara ekonomi syariah dapat diajukan dalam bentuk gugatan sederhana atau gugatan dengan dengan acara biasa.

PERMA ini juga mengatur pelaksanaan putusan arbitrase syariah dan pembatalannya yang mempertegas kewenangan pengadilan agama sehingga sudah tidak terjadi lagi dualisme pelaksanaan putusan dan pembatalan arbitrase syariah antara pengadilan agama dan pengadilan negeri. Hal ini termuat dalam Pasal 13 ayat (2) PERMA Sengketa Ekonomi Syariah yang menyebutkan bahwa pelaksanaan putusan arbitrase syariah dan pembatalannya, dilakukan oleh Pengadilan dalam lingkungan Peradilan Agama. Namun, tata cara pelaksanaan putusan arbitrase syariah tetap mengacu pada Undang-Undang Nomor 30 Tahun 1999 tentang Arbitrase dan Alternatif Penyelesaian Sengketa. Dalam PERMA ini juga mengatur kewenangan Pengadilan Agama yang menangani urusan eksekusi hak tanggungan dan fidusia yang menggunakan akad syariah. Hal ini dapat diperjelas dalam Pasal 13 ayat (1) dan (2) PERMA Sengketa 
Ekonomi Syariah, yaitu Pelaksanaan putusan perkara ekonomi syariah, hak tanggungan dan fidusia yang berdasarkan akad syariah dilakukan oleh Pengadilan dalam lingkungan Peradilan Agama dan Pelaksanaan putusan arbitrase syariah dan pembatalannya dilakukan oleh Pengadilan dalam lingkungan Peradilan Agama.

\section{b. Penyelesaian Sengketa Eksekusi Syariah Dalam Perspektif Undang-Undang Nomor 21 Tahun 2008 tentang Perbankan Syariah}

Sengketa Ekonomi Syariah secara rinci dapat dikemukakan mengenai bentukbentuk sengketa Bank Syariah yang disebabkan karena adanya pengingkaran atau pelanggaran terhadap perikatan (akad) yang telah dibuat, yaitu disebabkan karena :

1) Kelalaian Bank untuk mengembalikan dana titipan nasabah dalam akad wadi'ah.

2) Bank mengurangi nisbah keuntungan nasabah tanpa persetujuan yang bersangkutan dalam akad mudlorobah.

3) Nasabah melakukan kegiatan usaha minuman keras dan usaha-usaha lain yang diharamkan menurut syari' at Islam yang bersumber dari dana pinjaman bank syari'ah, akad qirah dan lain-lain.

4) Pengadilan Agama berwenang menghukum kepada pihak nasabah atau pihak bank yang melakukan wanprestasi yang menyebabkan kerugian riil (real lose).

Secara garis besar, sengketa ekonomi syari' ah dapat diklasifikasikan menjadi tiga, yakni:

1) Sengketa di bidang ekonomi syari'ah antara lembaga keuangan dan lembaga pembiayaan syari'ah dengan nasabahnya;

2) Sengketa di bidang ekonomi syari' ah antara lembaga keuangan dan lembaga pembiayaan syari'ah;

3) Sengketa di bidang ekonomi syari'ah antara orang-orang yang beragama Islam, yang mana akad perjanjiannya disebutkan dengan tegas bahwa kegiatan usaha yang dilakukan adalah berdasarkan prinsip-prinsip syari'ah.

Sengketa ekonomi syari'ah juga bisa dalam bentuk perkara Permohonan Pernyataan Pailit (PPP) dan juga bisa berupa Penundaan Kewajiban Pembayaran Utang (PKPU) di bidang ekonomi syari'ah, disamping itu juga perkara derivatif kepailitan (perkara tidak murni sebagai perkara kepailitan).Perkembangan pembangunan di segala bidang merupakan upaya untuk meningkatkan kesejahteraan lahir batin bagi warga masyarakat. Pembangunan itu sendiri dapat mempengaruhi pola pikir masyarakat 
terhadap pemecahan masalah hukum (law problem solving). Hubungan antara Bank Syariah dengan debitur tidak menutup kemungkinan timbulnya sengketa. Dalam hubungan yang terikat dalam akad, ada kalanya timbul sengketa diantara kedua belah pihak. Persengketaan antara debitur dengan Bank merupakan hal yang biasa terjadi di dalam dunia bisnis, seperti lembaga keuangan termasuk Bank Syariah.

Keberadaan Peradilan Agama bertujuan untuk menyelesaikan perkara yang timbul di antara anggota masyarakat. Perkara yang terjadi memiliki bentuk yang beragam. Ada yang berkenaan dengan pengingkaran atau perjanjian, perbuatan melanggar hukum, sengketa hak milik dan lain sebagainya. Timbulnya perkara tersebut ketika dihubungkan dengan keberadaan Peradilan Perdata, menimbulkan permasalahan kewenangan mengadili yang disebut yurisdiksi atau kompetensi yaitu kewenangan suatu lembaga Peradilan dalam mengadili perkara tertentu sesuai dengan ketentuan yang digariskan oleh peraturan perundang-undangan. ${ }^{5}$ Penyelesaian sengketa tidak boleh bertentangan dengan prinsip syariah, setelah seluruh tahap pemeriksaan selesai lalu hakim melanjutkan kerjanya untuk mengambil putusan dalam rangka mengadili perkara tersebut. Untuk itu hakim mencari hukumnya dari sumber-sumber yang sah dan menafsirkannya, untuk kemudian diterapkan kepada fakta atau peristiwa konkret yang ditemukan dalam perkara tersebut. Sumber-sumber hukum yang sah dan diakui secara umum, khususnya di bidang bisnis adalah isi perjanjian, undang-undang, yurisprudensi, kebiasaan, perjanjian internasional dan ilmu pengetahuan.

Rumusan Pasal 49 Undang-Undang Nomor 3 Tahun 2006 hampir sama dengan rumusan Pasal 49 Undang-Undang Nomor 7 Tahun 1989. Jika diamati secara eksplisit pasal-pasalnya seakan mengindikasikan bahwa tidak ada ruang bagi subjek dengan merujuk pada penjelasan Pasal 49 Undang-Undang Nomor 3 Tahun 2006 tentang Peradilan Agama, dimungkinkan bagi subjek hukum non muslim beracara di Pengadilan agama. Sehingga disimpulkan, bahwa sebenarnya subjek hukum non muslim dapat memproses penyelesaian sengketa ekonomi syariah di Pengadilan Agama.

Penyesuaian ini merupakan konsekuensi dari berkembangnya dunia ekonomi syariah, dimana tidak hanya orang yang beragama Islam saja yang menjalankan sistem perekonomian syariah serta menggunakan jasa perbankan syariah. Subjek hukum non

\footnotetext{
${ }^{5}$ Hasan, Hasbi, Kompetensi Peradilan Agama dalam penyelesaian perkara ekonomi Syariah, Gramata Publishing, Jakarta, 2010, hlm.121
} 
muslim yang menjalankan sistem syariah dan yang menggunakan jasa bank syariah, harus tunduk pada Undang-Undang Nomor 3 Tahun 2006 tentang Peradilan Agama. Selanjutnya, perubahan tersebut berimplikasi pada perubahan Undang-Undang Peradilan Agama. Di dalam undang-undang yang baru, dijelaskan bahwa sengketa ekonomi syariah menjadi salah satu kompetensi Peradilan Agama, selain kompetensi yang selama ini telah dijalankan.

Penyelesaian sengketa perbankan syariah berdasarkan kompetensi absolut Peradilan Agama ini melibatkan dua pasal yang krusial, yaitu Pasal 49 Undang-Undang Nomor 3 Tahun 2006 tentang Perubahan Atas Undang-Undang Nomor 7 Tahun 1989 tentang Peradilan Agama dan Pasal 55 Undang-Undang Nomor 21 Tahun 2008 tentang Perbankan Syariah. Kedua pasal tersebut mengatur bagaimana solusi bagi penyelesaian sengketa perbankan syariah. Ketentuan dalam Pasal 49 Undang-Undang Nomor 3 Tahun 2006 menyatakan memberikan kewenangan mutlak kepada peradilan dalam lingkungan Peradilan Agama untuk memeriksa, memutus dan menyelesaikan sengketa salah satunya adalah di bidang ekonomi syariah.

Pasca dikeluarkannya Undang-Undang Nomor 21 Tahun 2008 tentang Perbankan Syariah, pemberian kewenangan menyelesaikan perselisihan di bidang ekonomi syariah kepada peradilan dalam lingkungan Peradilan Agama tersebut menjadi bias. Terjadi inkonsistensi bahkan kerancuan dari sisi aturan main pembentukan peraturan perundang-undangan. Dalam Pasal 55 ayat (1) Undang-Undang Perbankan Syariah memang dinyatakan bahwa "penyelesaian sengketa perbankan syariah dilakukan pengadilan dalam lingkungan peradilan agama". Tafsir hukum yang dapat diberikan adalah telah menjadi prinsip hukum bahwa penyelesaian sengketa perbankan syariah menjadi kompetensi mutlak dalam proses litigasi peradilan dalam lingkungan Peradilan Agama. Pasal ini jelas mengungkapkan bahwa Peradilan Agama lah yang memiliki wewenang untuk menyelesaikan perkara-perkara ekonomi syariah terutama terkait dengan dunia perbankan lebih khusus lagi terkait dengan akad-akad atau kontraknya.

Namun kemudian muncul kontradiksi ketika mengamati Pasal 55 ayat (2) Undang-Undang Perbankan Syariah. Pasal ini menyatakan bahwa "Dalam hal para pihak telah memperjanjikan penyelesaian sengketa selain sebagaimana dimaksud pada ayat (1), penyelesaian sengketa dilakukan sesuai dengan isi akad”. Penjelasan Pasal 55 ayat (2) 
menyatakan bahwa yang dimaksud dengan penyelesaian sengketa dilakukan sesuai dengan isi akad adalah upaya sebagai berikut :

a. Musyawarah

b. Mediasi perbankan

c. Melalui BASYARNAS, dan/atau;

d. Melalui peradilan dalam lingkungan peradilan umum.

Tafsir hukum yang dapat diberikan adalah bahwa dalam penyelesaian perkaraperkara terkait dengan sengketa ekonomi syariah ini lebih mengutamakan klausula yang terdapat dalam isi akad atau kontrak para pihak. Artinya dalam sengketa ekonomi syariah ini kewenangan Peradilan Agama tidak mutlak, karena isi akad atau kontrak lebih utama daripada Undang-Undang Perbankan Syariah.

Terlihat bahwa ketentuan ayat (1) yang berisi penyelesaian sengketa secara litigasi harus berhadapan dengan ketentuan ayat (2) yang berisi penyelesaian sengketa secara non litigasi. Jika diperhatikan dalam struktur Undang-Undang Perbankan Syariah, maka penjelasan Pasal 55 ayat (2) memposisikan pengadilan dalam lingkungan Peradilan Umum sebagai lembaga penyelesaian sengketa non litigasi. Padahal sejatinya, lembaga peradilan umum adalah lembaga penyelesai sengketa litigasi. Tentu saja ini menimbulkan kerancuan, dan oleh karenanya penempatan norma tersebut dapat dikatakan salah (contradictio interminis).

Disamping itu, Negara Kesatuan Republik Indonesia telah memberikan kepercayaan yuridis kepada lembaga pengadilan dalam lingkungan peradilan agama tersebut. Oleh karena itu seharusnya tidak boleh ada satu anggapan perkiraan atau setengah-setengah dalam memberikan kepercayaan kepada lembaga pengadilan dalam lingkungan peradilan untuk menjadi satu-satunya wadah untuk menyelesaikan sengketa ekonomi syariah secara litigasi disamping penyelesaian sengketa ekonomi syariah non litigasi.

Pengadilan Agama seharusnya memang mendapatkan kepercayaan penuh dalam menyelesaikan sengketa ekonomi syariah, berdasarkan logika akademik, hakimhakim di lingkungan Pengadilan Agama sebagai arbitren fakultas syariah tentu akan memiliki pengetahuan dan pemahaman yang lebih baik mengenai ilmu-ilmu syariah, dalam hal ini fiqih muamalah, dibandingkan dengan hakim-hakim di Peradilan Umum, yang notabene tidak memiliki latar belakang ilmu-ilmu syariah. Logika sederhana 
semacam ini seharusnya menjadi argumen bahwa sangat tidak logis meragukan profesionalitas dan kredibilitas hakim-hakim di Peradilan Agama dalam menangani sengketa perbankan syariah.

\section{c. Kewenangan Pengadilan Agama dalam Eksekusi Sengketa Ekonomi Syariah}

Semenjak tahun 2006, dengan diamandemennya Undang-Undang Nomor 7 Tahun 1989 dengan Undang-Undang Nomor 3 Tahun 2006, kewenangan Pengadilan Agama diperluas. Di samping berwenang memeriksa, memutus dan menyelesaikan sengketa di tingkat pertama antara orang-orang yang beragama Islam di bidang perkawinan, waris, wasiat, hibah, wakaf, zakat, infaq dan shadaqah. Pengadilan Agama juga berwenang untuk memeriksa, memutus dan menyelesaikan sengketa di bidang ekonomi syariah (Pasal 49 huruf i Undang-Undang Nomor 3 Tahun 2006). Kewenangan Pengadilan Agama ini juga diperkuat dengan putusan Mahkamah Konstitusi atas perkara No. 93/PUU-X/2012 yang menghapuskan penjelasan Pasal 55 ayat (2) Undang-Undang Nomor 21 Tahun 2008 tentang Perbankan Syariah, sehingga menjadikan Pengadilan Agama satu-satunya lembaga Pengadilan yang berwenang untuk menyelesaikan sengketa ekonomi syariah.

Pengadilan Agama merupakan salah satu wadah bagi umat Islam pencari keadilan dalam merealisasikan rasa keadilan, norma serta nilai keislaman sesuai dengan ketentuan syariat Islam. Disinilah peran Qadhi atau hakim agama dalam menegakkan keadilan dan memberantas kezhaliman yang ada. Di Indonesia, dalam merealisasikan dan melaksanakan perintah tersebut ada tahapan-tahapan yang harus dilaksanakan sesuai dengan aturan yang berlaku, mulai dari jenis perkara yang disidangkan sesuai sebagaimana diatur dalam Pasal 49 Undang-Undang Nomor 3 Tahun 2006 tentang kewenangan absolut Peradilan Agama yang khusus menetapkan dan memutuskan perkara perdata masyarakat yang beragama Islam dan hal lainnya yang diatur dalam Undang-Undang. Dari jenis perkara tersebut diakhir sidang hakim akan memutus perkara sesuai dengan jenis perkaranya yang kelak hasilnya disebut dengan putusan atau penetapan. $^{6}$

${ }^{6}$ Abdul Manan, Hukum Ekonomi Syariah dalam Perspektif Kewenangan Peradilan Agama, Kencana, Jakarta, 2012, hlm.59. 
Putusan merupakan hasil akhir dari sengketa. Putusan secara pengertian umum merupakan pernyataan hakim, sebagai pejabat negara yang diberi wewenang untuk itu, diucapkan di persidangan dan bertujuan untuk mengakhiri atau menyelesaikan suatu sengketa antara para pihak. Bukan hanya ucapan saja yang disebut putusan, melainkan juga pernyataan yang dituangkan dalam bentuk tertulis dan kemudian diucapkan hakim di depan persidangan. Adapun produk hakim di Pengadilan Agama dari hasil pemeriksaan perkara di persidangan ada dua macam berdasarkan Pasal 60 UndangUndang Nomor 5 Tahun 2009, yaitu putusan dan penetapan. Putusan adalah pernyataan hakim yang dituangkan dalam bentuk tertulis dan diucapkan oleh hakim dalam persidangan atas perkara gugatan berdasarkan adanya suatu sengketa. Penetapan adalah pernyataan hakim yang dituangkan dalam bentuk tertulis dan diucapkan oleh hakim dalam persidangan atas perkara permohonan.

Dari produk itulah yang selanjutnya menjadi pegangan dari para pihak yang dimenangkan untuk dapat melaksanakan tahap selanjutnya berupa pelaksanaan putusan atau eksekusi. Oleh karena itu, keberhasilan seseorang pencari keadilan untuk memulihkan, mengembalikan ataupun memperoleh hak-haknya kembali masih menunggu dilaksanakannya putusan hakim tersebut oleh pihak lawan. Hal ini akan dapat diwujudkan melalui eksekusi putusan hakim oleh aparat hukum di Pengadilan Agama.

\section{Bentuk Perlindungan Hukum Debitur Apabila Sengketa Lelang Perbankan Syariah Sudah Ditetapkan Oleh Pengadilan Negeri.}

Posisi nasabah sangatlah lemah bila dibandingkan dengan posisi Bank, baik Bank Konvensional maupun Bank Syariah. Setidaknya ada dua hubungan hukum antara Bank dengan nasabah yang dinilai tidak adil. Pertama, ketika Bank bertindak sebagai kreditur, nasabah memberikan perlindungan hukum dalam bentuk penyerahan dokumen atau agunan guna menjamin pelunasan hutang nasabah. Hal semacam ini tentu menguntungkan pihak Bank. Kedua, nasabah sama sekali tidak menguasai dokumen atau agunan dari Bank guna menjamin hutang Bank ke nasabah dalam bentuk giro, deposito, tabungan atau bentuk lainnya. Nasabah hanya berbekal kepercayaan saja kepada Bank. Ini juga tentunya menguntungkan Bank.

Praktek perbankan juga menempatkan konsumen dalam posisi yang semakin lemah. Bank dilindungi dengan perjanjian standar perbankan dalam bentuk berbagai klausula sepihak yang dibuat oleh pihak Bank. Nasabah dipaksa tunduk terhadap segala 
petunjuk dan peraturan Bank, baik yang sudah berlaku maupun yang akan diberlakukan kemudian tanpa mempersoalkan setuju tidaknya nasabah terhadap ketentuan-ketentuan yang ada. Keadaan yang demikian menuntut adanya perlindungan hukum bagi nasabah Bank Syariah. Hukum seharusnya memberikan perlindungan terhadap semua pihak sesuai dengan status hukumnya karena pada prinsipnya setiap orang memiliki kedudukan yang sama dihadapan hukum. Dalam perwujudannya, negara wajib memberikan perlindungan hukum secara nyata kepada setiap warga negaranya tanpa terkecuali yang pelaksanaannya dirumuskan dalam bentuk peraturan perundang-undangan.

Perlindungan hukum tidak memiliki pengertian yang secara khusus diatur di dalam peraturan perundang-undangan. Namun secara umum pengertian perlindungan hukum dapat dijumpai dari pernyataan Satjipto Rahardjo yang menyatakan bahwa perlindungan hukum adalah perlindungan terhadap hal dan kepentingan pribadi setiap pihak berdasarkan hukum yang berlaku. ${ }^{7}$ Menurut Sulistyandari, yang dimaksud dengan perlindungan hukum adalah segala hal yang berkaitan bagaimana hukum memberikan keadilan, yaitu memberikan atau mengatur hak dan kewajiban subyek hukum, selain itu juga berkaitan bagaimana hukum memberikan keadilan terhadap subyek hukum yang dilanggar haknya untuk mempertahankan haknya tersebut. ${ }^{8}$

Perlindungan hukum merupakan gambaran dari bekerjanya fungsi hukum untuk mewujudkan tujuan-tujuan hukum, yakni keadilan, kemanfaatan, dan kepastian hukum. Perlindungan hukum adalah suatu perlindungan yang diberikan kepada subyek hukum sesuai dengan aturan hukum, baik itu yang bersifat preventif (pencegahan) maupun dalam bentuk yang bersifat represif (pemaksaan), baik secara tertulis maupun tidak tertulis dalam rangka menegakkan aturan hukum.

Menurut Marulak Mardede sebagaimana dikutip oleh Hermansyah, mengemukakan bahwa perlindungan hukum terhadap nasabah dalam sistem perbankan Indonesia dapat dilakukan melalui dua cara yaitu : ${ }^{9}$

a. Perlindungan secara implisit (implicit deposit protection), yaitu perlindungan yang dihasilkan oleh pengawasan dan pembinaan Bank yang efektif, yang dapat menghindarkan terjadinya kebangkrutan Bank. Perlindungan ini diperoleh melalui :

\footnotetext{
${ }^{7}$ Satjipto Rahardjo, Ilmu Hukum, Alumni, Bandung, 1986, hlm.94.

8 Sulistyandari, Hukum Perbankan Perlindungan Hukum Terhadap Nasabah Penyimpan Melalui Pengawasan Perbankan di Indonesia, Laros, Sidoarjo, 2012, hlm.283.

${ }^{9}$ Hermansyah, Hukum Perbankan Nasional Indonesia, Kencana, Jakarta, 2013, hlm. 145-146.
} 
1) Peraturan perundang-undangan di bidang perbankan;

2) Perlindungan yang dihasilkan oleh pengawasan dan pembinaan yang efektif, yang dilakukan oleh Bank Indonesia;

3) Upaya menjaga kelangsungan usaha Bank sebagai sebuah lembaga pada khususnya dan perlindungan terhadap sistem perbankan pada umumnya;

4) Memelihara tingkat kesehatan Bank;

5) Cara pemberian kredit yang tidak merugikan Bank dan kepentingan nasabah;

6) Menyediakan informasi risiko pada nasabah;

b. Perlindungan secara eksplisit (explicit deposit protection), yaitu perlindungan melalui pembentukan suatu lembaga yang menjamin simpanan masyarakat, sehingga apabila Bank mengalami kegagalan, lembaga tersebut yang akan mengganti dana masyarakat yang disimpan pada Bank yang gagal. Perlindungan ini diperoleh melalui pembentukan lembaga yang menjamin simpanan masyarakat, sebagaimana diatur dalam Keputusan Presiden Republik Indonesia Nomor 26 Tahun 1998 tentang Jaminan Terhadap Kewajiban Bank Umum.

\section{a. Faktor-Faktor Yang Menyebabkan Penyelesaian Sengketa Perbankan Syariah Masih Diselesaikan di Pengadilan Negeri}

Sebagaimana lazimnya dalam menangani setiap perkara yang diajukan kepadanya, hakim selalu dituntut untuk mempelajari terlebih dahulu perkara tersebut secara cermat untuk mengetahui substansinya hal ikhwal yang senantiasa ada yang menyertai substansi perkara tersebut. Untuk itu hakim harus sudah mempunyai resume tentang perkara yang ditanganinya sebelum dimulainya proses pemeriksaan di persidangan. Berkaitan dengan hal tersebut, dalam hal memeriksa perkara ekonomi syariah khususnya pada perbankan syariah, ada beberapa penting yang harus dilakukan terlebih dahulu sebelum proses persidangan dimulai. Adapun hal-hal penting yang harus dilakukan yaitu: ${ }^{10}$

a) Pastikan lebih dahulu perkara tersebut bukan perkara perjanjian yang mengandung klausul arbitrase;

b) Mempelajari secara cermat perjanjian (akad) yang mendasari kerjasama antar para pihak.

${ }^{10}$ Basir, Cik, Penyelesaian Sengketa Perbankan Syariah di Pengadilan Agama dan Mahkamah Syariah, Kencana, Jakarta, 2009, hlm. 132. 
Pada kenyataannya, meskipun pengaturan penyelesaian sengketa perbankan syariah telah menjadi kewenangan Pengadilan Agama, akan tetapi masih ada saja penyelesaian sengketa perbankan syariah yang diajukan ke Pengadilan Negeri. Salah satu contoh kasus sengketa yang masih menggunakan Pengadilan Negeri untuk menyelesaikan sengketa syariah adalah perkara antara Setya Rahyudi dengan PT. Bank Syariah Mandiri Kantor Cabang Jemur Handayani Surabaya. Dalam akad pembiayaan telah disepakati apabila terjadi perselisihan, penyelesaian yang digunakan adalah melalui Pengadilan Negeri Sidoarjo. Dari ketentuan diatas, bahwa penyelesaian sengketa antara kedua belah pihak diselesaikan melalui Pengadilan Negeri Sidoarjo. Padahal jika mengacu pada Putusan Mahkamah Konsitusi Nomor 93/PUU-X/2012 maka seharusnya penyelesaian sengketa syariah adalah kewenangan Pengadilan Agama. Oleh sebab itu, adapun faktor-faktor yang mempengaruhi masih adanya penyelesaian sengketa perbankan syariah yang diajukan ke Pengadilan Negeri adalah sebagai berikut:

1) Faktor adanya choice of forum

Ketentuan penyelesaian sengketa yang tertera di dalam akad yang telah disepakati oleh para pihak yaitu nasabah dengan Bank. Berdasarkan ketentuan tersebut para pihak telah memilih Pengadilan Negeri untuk menyelesaikan perselisihan dikemudian hari yang dituangkan dalam perjanjian (akad). Pada dasarnya setiap kontrak yang dibuat oleh para pihak harus dapat dilaksanakan dengan itikad baik. Dalam hal ini kontrak yaitu bertemunya ijab yang diberikan oleh salah satu pihak dengan qabul yang diberikan oleh pihak lainnya secara sah menurut hukum syar'i dan menimbulkan akibat pada obyeknya.

Dalam pelaksanaan kontrak di Lembaga Keuangan Syariah, sering terjadi perselisihan pendapat baik dalam penafsiran maupun dalam implementasi isi perjanjian. Persengketaan tersebut harus segera diantisipasi dengan cermat untuk menemukan solusi bagi pihak Lembaga Keuangan Syariah maupun nasabah. Untuk mengantisipasi persengketaan ekonomi syariah yang terjadi di Lembaga Keuangan Syariah, baik masyarakat, Lembaga Keuangan Syariah baik Bank maupun non Bank, serta para pengguna jasanya menyadari bahwa mereka tidak dapat 
mengandalkan instansi Peradilan Umum apabila benar-benar mau menegakkan prinsip syariah. ${ }^{11}$

2) Faktor hakim tidak boleh menolak perkara

Sebagai sebuah profesi yang berkaitan dengan proses di Pengadilan, definisi hakim menyebutkan hakim adalah pejabat peradilan Negara yang diberi wewenang oleh Undang-Undang untuk mengadili. Mengadili diartikan sebagai serangkaian tindakan hakim untuk menerima, memeriksa dan memutus perkara berdasarkan asas bebas, jujur, dan tidak memihak di sidang Pengadilan dalam hal menuntut dan tata cara yang diatur dalam Undang-Undang. Hakim memiliki kedudukan dan peranan yang sangat penting demi tegaknya negara hukum. Oleh karena itu terdapat beberapa nilai yang dianut dan wajib dihormati oleh penyandang profesi hakim dalam menjalankan tugasnya. Nilai-nilai tersebut adalah:

a. Profesi hakim adalah profesi yang merdeka guna menegakkan hukum dan keadilan berdasarkan Pancasila demi terselenggaranya negara hukum Republik Indonesia. Disini terkandung nilai kemerdekaan dan keadilan.

b. Selanjutnya, nilai keadilan juga tercermin dari kewajiban hakim untuk menyelenggarakan peradilan secara sederhana, cepat dan biaya ringan agar keadilan tersebut dapat dijangkau semua orang. Dalam mengadili, hakim juga tidak boleh membeda-bedakan orang dan wajib menghormati asas praduga tak bersalah.

c. Kewajiban menegakkan keadilan ini tidak hanya dipertanggungjawabkan secara horizontal kepada sesama, tetapi juga secara vertikal kepada Tuhan Yang Maha Esa. Hakim tidak boleh menolak untuk memeriksa dan mengadili suatu perkara yang diajukan dengan dalih bahwa hukumnya tidak ada atau tidak jelas. Apabila hakim melihat adanya kekosongan hukum karena tidak ada atau kurang jelasnya hukum yang mengatur suatu hal, maka ia wajib menggali nilai-nilai hukum yang hidup di masyarakat. Nilai ini juga disebut nilai keterbukaan.

d. Hakim menjunjung tinggi kerjasama dan kewibawaan korps. Nilai kerjasama ini tampak dari persidangan yang berbentuk majelis, dengan sekurang-

11 Warkum Sumitro, Op. cit., hlm. 30. 
kurangnya dari tiga orang hakim. Sebelum menjatuhkan putusannya, para hakim ini melakukan musyawarah secara tertutup.

e. Hakim harus senantiasa mempertanggungjawabkan segala sikap dan tindakannya. Secara vertikal berarti ia bertanggung jawab kepada Tuhan Yang Maha Esa. Sedangkan pertanggungjawaban secara horizontal berarti ditujukan kepada manusia, baik kepada lembaga peradilan yang lebih tinggi maupun kepada masyarakat luas. Berkaitan dengan pertanggungjawaban horizontal. Pasal 25 ayat (1) Undang-Undang Kekuasaan Kehakiman menyebutkan bahwa : "Segala putusan Pengadilan selain harus memuat alasan dan dasar putusan tersebut, memuat pula pasal tertentu dari perundang-undangan yang bersangkutan atau sumber-sumber hukum tak tertulis yang dijadikan dasar untuk mengadili.

Oleh karena itu Pengadilan Negeri juga tidak dapat menolak perkara yang diajukan kepadanya termasuk sengketa perbankan syariah. Apabila hakim menolak perkara yang diajukan kepadanya maka hakim dianggap mengingkari rasa keadilan yang seharusnya ditegakkan. Hakim sebagai salah satu perangkat Pengadilan ditugaskan untuk menetapkan hubungan hukum yang sebenarnya antara kedua belah pihak yang bersengketa, yang sekaligus melakukan konkretisasi hukum terhadap perkara-perkara yang belum ada hukumnya.

\section{3) Faktor Kurangnya Sosialisasi Hukum}

Faktor ini berkaitan dengan penyelesaian sengketa perbankan syariah yang dianggap perlu dilakukan sosialisasi hukum secara terus menerus oleh badan legislatif. Secara yuridis, pencantuman Pasal 55 ayat (2) Undang-Undang Nomor 21 Tahun 2008 tentang Perbankan Syariah mengingat keberadaannya telah ditampung Pasal 49 Undang-Undang Nomor 3 Tahun 2006 tentang Peradilan Agama yang secara tegas memberikan kewenangan kepada Pengadilan Agama untuk menerima dan menyelesaikan sengketa ekonomi syariah termasuk didalamnya Perbankan Syariah. Hal tersebut diperkuat dan dipertegas kewenangan Peradilan Agama dalam menyelesaikan sengketa ekonomi syariah, dengan adanya Putusan Mahkamah Konstitusi Nomor 93/PUU-X/2012 yang membatalkan Penjelasan Pasal 55 ayat (2) Undang-Undang Nomor 21 Tahun 2008 tentang Perbankan Syariah, karena dianggap bertentangan 
dengan Pasal 28 D ayat (1) Undang-Undang Dasar Negara Kesatuan Republik Indonesia Tahun 1945 (UUD 1945). Sosialisasi tersebut khususnya ditujukan kepada pihak bank syariah dan para notaris yang biasanya menentukan substansi dari perjanjian perbankan syariah, karena pada dasarnya akad (perjanjian) yang dibuat oleh pihak bank dengan nasabah merupakan perjanjian baku yang telah dipersiapkan oleh pihak bank tersebut. Oleh karena itu yang menentukan pilihan hukum terhadap penyelesaian sengketa adalah pihak bank syariah sendiri.

\section{PENUTUP}

\section{Kesimpulan}

Dengan penjelasan yang telah dijelaskan pada bab-bab sebelumnya, penulisan tesis ini diperoleh kesimpulan :

a. Karakteristik sengketa Bank Syariah dapat berbentuk kemacetan dalam pelunasan pembiayaan oleh nasabah debitur atau tidak amannya dana masyarakat yang disimpan di Bank Syariah dan Bank Syariah tidak mampu lagi membayar saat nasabah penyimpan melakukan penarikan dana yang dananya disimpan kepadanya. Jadi, sengketa yang terjadi dapat timbul dari nasabah debitur atau Bank Syariah itu sendiri. Biasanya yang menjadi faktor utama terjadinya sengketa adalah karena telah dipenuhinya akad yang telah diperjanjikan antara Bank Syariah dengan nasabah atau tidak dipenuhinya akad yang telah diperjanjikan antara Bank Syariah dengan nasabah atau tidak dipenuhinya prinsip syariah dalam akad tersebut.

b. Pengadilan Negeri berwenang menyelesaikan sengketa perbankan syariah sebagaimana diatur di dalam Pasal 55 Undang-Undang Perbankan Syariah. Pasal 55 Undang-Undang Perbankan Syariah sebagai undang-undang menentukan Pengadilan Agama sebagai lembaga yang berwenang untuk menyelesaikan sengketa perbankan syariah. Namun Undang-Undang Perbankan Syariah juga memberikan kewenangan lain melalui perjanjian, bahwa sengketa perbankan syariah dapat ditangani dengan musyawarah, mediasi perbankan, badan arbitrase syariah nasional atau lembaga arbitrase lain serta melalui Pengadilan dalam lingkungan Peradilan Umum.

\section{Saran}


Agar penyelesaian sengketa-sengketa bidang ekonomi syariah umumnya, dan bidang perbankan syariah pada khususnya di Pengadilan Agama dapat benar-benar relevan dengan prinsip-prinsip syariah maka diperlukan adanya hukum acara (hukum formil) yang secara khusus berlaku bagi lingkungan Peradilan Agama dalam menyelesaikan perkaraperkara di bidang ekonomi tersebut. Sehubungan dengan itu, kepada pada legislator khususnya Dewan Perwakilan Rakyat (DPR) dan juga Pemerintah agar sesegera mungkin dapat mengupayakan adanya hukum acara tersebut bagi lingkungan Peradilan Agama. Sementara belum ada aturan dimaksud, diharapkan agar Mahkamah Agung dapat mengeluarkan pedoman teknis baik dalam bentuk Peraturan Mahkamah Agung (SEMA) guna menunjang pelaksanaan tugas Peradilan Agama dalam menjalankan kewenangan tersebut.

\section{DAFTAR BACAAN}

\section{$\underline{\text { Buku }}$}

Rachmadi Usman, Produk dan Akad Perbankan Syariah di Indonesia, Citra Aditya Bakti, Bandung, 2009;

Pius A Partanto, Kamus Ilmiah Populer, Arkola, Surabaya, 2001;

Peter Mahmud Marzuki, Penelitian Hukum, Kencana Prenada Media Group, Jakarta, 2005;

Mardani, Hukum Acara Perdata Peradilan Agama dan Mahkmah Syariah, Sinar Grafika, Jakarta, 2009;

Hasan, Hasbi, Kompetensi Peradilan Agama dalam penyelesaian perkara ekonomi Syariah, Gramata Publishing, Jakarta, 2010;

Abdul Manan, Hukum Ekonomi Syariah dalam Perspektif Kewenangan Peradilan Agama, Kencana, Jakarta, 2012;

Satjipto Rahardjo, Ilmu Hukum, Alumni, Bandung, 1986;

Sulistyandari, Hukum Perbankan Perlindungan Hukum Terhadap Nasabah Penyimpan Melalui Pengawasan Perbankan di Indonesia, Laros, Sidoarjo, 2012;

Hermansyah, Hukum Perbankan Nasional Indonesia, Kencana, Jakarta, 2013;

Basir, Cik, Penyelesaian Sengketa Perbankan Syariah di Pengadilan Agama dan Mahkamah Syariah, Kencana, Jakarta, 2009. 


\section{Peraturan Perundang-Undangan}

Kitab Undang-Undang Hukum Perdata

Undang-Undang Nomor 10 Tahun 1998 Tentang Perubahan Atas Undang-Undang Nomor 7

Tahun 1972 Tentang Perbankan

Undang-Undang Nomor 21 Tahun 2008 Tentang Perbankan Syariah

Undang-Undang Nomor 2 Tahun 1986 Tentang Peradilan Umum

Undang-Undang Nomor 30 Tahun 1999 Tentang Arbitrase

Undang-Undang Nomor 3 Tahun 2006 Tentang Perubahan Atas Undang-Undang Nomor 7

Tahun 1989 Tentang Peradilan Agama

Undang-Undang Nomor 30 Tahun 1999 Tentang Arbitrase Dan Alternatif Penyelesaian Sengketa

Undang-Undang Nomor 4 Tahun 2004 Tentang Kekuasaan Kehakiman

Undang-Undang Nomor 4 Tahun 1996 Tentang Hak Tanggungan

Peraturan Pemerintah Nomor 72 Tahun 1992 Tentang Bank Berdasarkan Bagi Hasil

Keputusan Presiden Republik Indonesia Nomor 26 Tahun 1998 Tentang Jaminan Terhadap Kewajiban Bank Umum

Peraturan Menteri Keuangan Nomor 40/Pmk/07/2006 Tentang Petunjuk Pelaksanaan Lelang

Peraturan Bank Indonesia Nomor 10/18/Pbi/2008 Tentang Restrukturisasi Pembiayaan Bagi Bank Syariah Dan Unit Usaha Syariah

Peraturan Mahkamah Agung Republik Indonesia Nomor 14 Tahun 2016 Tentang Tata Cara Penyelesaian Sengketa Ekonomi Syariah

Peraturan Mahkamah Agung Republik Indonesia Nomor 2 Tahun 2008 Tentang Kompilasi Hukum Ekonomi Syariah 